\title{
Determination of the Planning Target Volume Margin by the Use of kv Portal Imaging and kvCone Beam Computerized Tomography
}

\author{
Gozde YAZICI ${ }^{1}$, Mete YEGINER ${ }^{1}$, Meltem ATAMEL ${ }^{2}$, Pervin HURMUZ ${ }^{1}$, Melis GULTEKIN ${ }^{1}$, \\ Mustafa CENGIZ ${ }^{1}$, Ferah YILDIZ ${ }^{1}$, Gokhan OZYIGIT ${ }^{1}$
}

\author{
${ }^{1}$ Hacettepe University Faculty of Medicine, Department of Radiation Oncology, Ankara \\ ${ }^{2}$ Near East University Faculty of Medicine, Department of Radiation Oncology, Mersin, TURKEY
}

\begin{abstract}
With portal imaging devices we can easily determine the position of bones in the patient, but we cannot visualize soft tissues. Kilo voltage cone beam computed tomography (CBCT) imaging integrated to treatment machine is relatively a new technique and provides higher resolution of soft tissues for imaging. In this study, our aim was to measure the differences between 2D-2D and 3D-3D registration based set-ups. We investigated whether using $\mathrm{kV}$ cone beam CT reduced setup errors compared to kV portal imaging. Four patients with the diagnosis of head and neck cancer (2 patients with cancer in the base of tongue, 2 with hypopharyngeal cancer) and 6 patients with prostate cancer were included in our study. The treatments were delivered with IMRT. KVCBCT-kv film comparisions were evaluated in 44 sets of data for head and neck cancer patients, and in 130 sets of data for prostate cancer patients. We analyzed the necessary planning target volume (PTV) margins for each group when only kv portal imaging is performed every day and found that a margin of 2.1 and $1.5 \mathrm{~mm}$ in all directions would be sufficient in case of pelvic tumors and head and neck cancers respectively if the kv portal images are performed every day. Compared to the literature the shifts were minimal when kVCBCT was performed after $\mathrm{kv}$ portal imaging. The immobilization procedures, followed strictly, may be reason for this observation.
\end{abstract}

Keywords: Planning target volume margin, Set-up margin, kv portal imaging, Cone beam computed tomography

ÖZET

kv Portal Görüntüleme ve kvCone Beam Bilgisayarlı Tomografi ile Planlanan Hedef Hacim Sınırlarının Belirlenmesi

Portal görüntüleme yöntemleri ile hastanın kemik yapılarını kolayca görüntüleyebiliriz, ancak yumuşak dokular bu yöntemle izlenemez. Kilo voltaj cone beam bilgisayarı tomografi (CBCT) görüntüleme yöntemlerinin tedavi cihazlarına entegre edilmesi nispeten yeni bir yöntemdir ve yumuşak dokuların daha yüksek çözünürlükte görüntülemesini sağlar. Bu çalışmada amacımı iki buyutlu görüntüleme işlemleri ile yapılan set-up ile üç boyutlu görüntüleme yöntemleri ile yapılan set-up arasındaki farkı araştırmak ve set-up hataları açısından kvCBCT nin portal görüntülemeye göre set-up hatalarını ne kadar düzelttiğni incelemektir. Dört baş ve boyun kanserli (2 hasta dil kökü, 2 hasta hipofarinks) ve dört prostat kanserli hasta çalışmaya dahil edildi. Tedaviler yoğunluk ayar॥ radyoterapi (YART) yöntemi ile uygulandı. Baş boyun kanserli hastalardan elde olunan 44 kvCBCT-kv portal film karşılaştırması ve prostat kanserli hastalardan elde olunan 130 kvCBCT-kv portal film karşılaştırması değerlendirildi. Analizler sonucunda her gün sadece kv portal görüntüleme yapıldığında gerekli PTV emniyetinin baş boyun kanserleri için $1.5 \mathrm{~mm}$ ve prostat kanseri için $2.1 \mathrm{~mm}$ olduğu bulundu. Literatür ile kıyaslandığında kv portal görüntüleme sonrası kvCBCT uygulandığında kaymaların minimal olduğu bulunmuştur. Bunun nedenlerinden biri immobilizasyon yöntemlerinin ve hazırlık aşamalarının her hasta için özenle uygulanmış olması olabilir.

Anahtar Kelimeler: Planlanan hedef hacim marjı, Set-up marjı, Portal görüntüleme, Cone beam bilgisayarlı tomografi 


\section{INTRODUCTION}

The technological developments in radiotherapy, like intensity modulated radiotherapy (IMRT), resulted in decreased normal tissue complication rates. ${ }^{1}$ With this technique high doses of radiation to the target could be delivered while sparing the adjacent critical tissues with rapid dose fall-off outside the clinical target volume. ${ }^{2}$ However, high accuracy in target delineation and delivery is needed so as to prevent marginal recurrences.

Laser localization lights, skin tattoos, and body stabilizing devices are the traditional techniques used for set-up purposes. These precautions were adequate in the era when conventional radiotherapy techniques were used. As we obtain steep dose gradients with IMRT, we need more delicate image guidance devices to prevent marginal misses and unintentional hot spots in critical organs. Various image guidance techniques are used in practice for different kind of tumor localizations; fiducial marker tracing, electronic portal imaging (EPID), $\mathrm{kV}$ portal imaging, and cone beam CT are examples for image guidance. ${ }^{3,4}$

With portal imaging devices we can easily determine the position of bones in the patient and they are routinely used for verification/correction of the pretreatment patient positioning. However, this technique cannot visualize soft tissues. Fiducial seeds, ultrasound, computed tomography on rails, megavoltage computed tomography are modalities that provide the visualization and localization of softtissues. Kilo voltage cone beam computed tomography (CBCT) imaging integrated to treatment machine is relatively a new technique and provides higher resolution of soft tissues for imaging. ${ }^{5}$

In this study, our aim was to measure the differences between 2D-2D and 3D-3D registration based set-ups. We were interested in the degree of target volume motion with respect to the bony structures as assessed by CBCT imaging. We investigated whether using $\mathrm{kV}$ cone beam $\mathrm{CT}$ reduced setup errors compared to $\mathrm{kV}$ portal imaging. Our secondary objective was to calculate the PTV margin in case of $\mathrm{kV}$ portal imaging for daily set-up as the use of $\mathrm{CBCT}$ is not widespread.

\section{MATERIALS AND METHODS}

Ten patients treated from April 2011 to July 2011 were evaluated retrospectively. Four patients with the diagnosis of head and neck cancer (2 patients with cancer in the base of tongue, 2 with hypopharyngeal cancer) and 6 patients with prostate cancer were included in our study. The treatments were delivered with IMRT.

Patients treated for prostate cancer were given written instructions for bowel preparation, and were asked to follow them before simulation and every treatment session. The attending physician also explained the preparation procedure thoroughly to the patients. The patients were instructed to empty their bowel 1 to 2 hours before treatment schedule. When they arrived at the department for simulation they were instructed to empty their bladder first and then they drank $500 \mathrm{ml}$ of water in 15 minutes. Forty minutes after finishing their water the simulation procedure started. These routines were also performed before every treatment. Patients were immobilized using a deformable cushion (Vac-Lok, CIVCO Medical Solutions, Kalona, IA) $25 \times 50 \mathrm{~cm}$ in size.

Patients treated for head and neck cancers were stabilized using head-neck and shoulder thermoplastic mask with fixation at 9 points (Zentec, CIVCO Medical Solutions, Kalona, IA). Standart head rest, knee and feet stabilizers, and shoulder extenders were used for all patients (Combifix, CIVCO Medical Solutions, Kalona, IA). The headrest was affixed to a baseplate.

CT scans with a slice thickness of $2.5 \mathrm{~mm}$ were acquired (G\&E, discovery HD, CT750). The studies were transferred to Eclipse 8.9 (Varian Medical Systems, Inc., Palo Alto, CA) workstation for contouring of the clinical target volume, planning target volume and organs at risk. All patients received IMRT with Varian Rapid Arc linear accelerator.

Initial patient positioning adjustments were made by aligning surface markers placed at the time of simulation. Following this initial set-up, anteroposterior and lateral $\mathrm{kv}$ radiographs were acquired for bony structure visualization. These $\mathrm{kv}$ films, obtained before every treatment, were compared with digitally reconstructed images (DRR) of simulation films (2D-2D registration). The shifts according to 


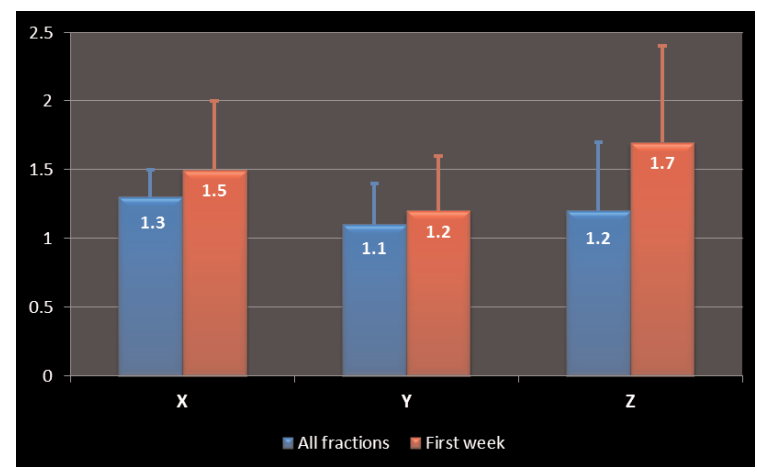

Figure 1. The average and standard deviations of the final shifts for pelvis cases in $X, Y$ and $Z$ directions. The first (blue) and second (red) bars represent the values for all fractions and the first week, respectively.

bony structures were performed before every treatment session. These shifts were performed by a radiation therapist and were approved by a radiation oncologist.

kvCBCT were taken with a slice thickness of 2.5 $\mathrm{mm}$. Simulation CT and kvCBCT images were fused to detect the shift according to the soft tissue structures. The CT images were inspected at axial, coronal, sagittal cross sections by the attending radiation oncologist. The shifts for $\mathrm{X}, \mathrm{Y}$, and $\mathrm{Z}$ axis were recorded.

For patients receiving radiotherapy to pelvic region, first the kv portal images were taken and the set-up was performed according to bony structures. Then, kvCBCT was performed, and the final shifts according to soft tissues were carried out before treatment delivery. In the treatment of head and neck cancer patients the portal images were performed as described above for the first week. In the following weeks $\mathrm{kv}$ portal images and kvCBCT were performed once a week while the other days the set-up was practiced with only kv portal imaging.

The required additional PTV margin for the center in which $\mathrm{kV}$ portal imaging system is used is calculated using the models of van Herk et al. and Parker et al. ${ }^{6,7}$ The models are defined as where $\Sigma$ and $\sigma$ are the standard deviations of systematic errors and random errors, respectively. $\Sigma$ is calculated as the standard deviation of average shifts for all patients whereas $\sigma$ is the root mean square of the individual standard deviations of the shifts for all patients.

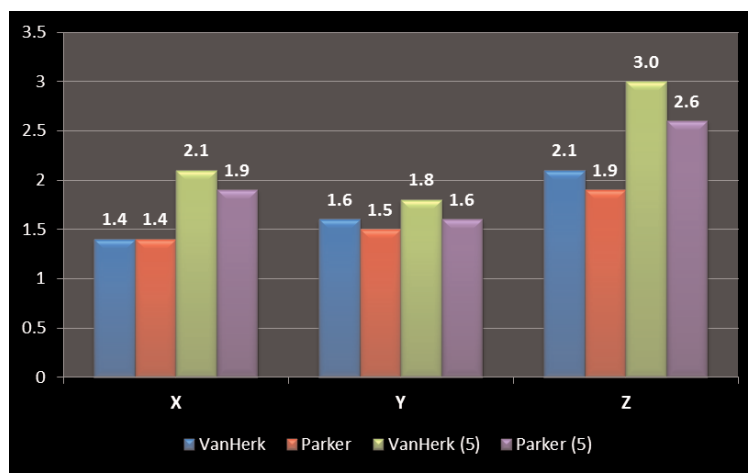

Figure 2. The estimated margins using van Herk and Parker models for pelvis cases. The first two columns (blue and red) in $X, Y$ and $Z$ directions represent the margin values for all fractions. The third (green) and fourth (purple) columns represent the values for the first week.

\section{RESULTS}

kvCBCT-kv film comparisions were evaluated in 44 sets of data for head and neck cancer patients, and were evaluated in 130 sets of data for prostate cancer patients. The data analyses of H\&N and pelvis patients are carried out separately in order to observe and characterize the shifting of target volume with respect to the tumor localization. The average values of the final shifts of six prostate patients are shown in Figure 1. The first columns in X, Y and Z directions represent the averages of the measurements taken during all fractions of a treatment while the second columns represent the averages of the first week measurements. The all average values are in the range of $1.1 \mathrm{~mm}$ and $1.7 \mathrm{~mm}$. The average final shifts of the first week measurements are higher than those of all fractions with the ratios of $15 \%, 9 \%$ and $42 \%$ in $\mathrm{X}, \mathrm{Y}$ and $\mathrm{Z}$ directions, respectively.

The additional PTV margins for prostate cases calculated using the models of van Herk and Parker are shown in Figure 2. In $\mathrm{X}$ and $\mathrm{Y}$ directions, the correction margins are around $1.5 \mathrm{~mm}$ and have the values between $1.4 \mathrm{~mm}$ and $1.6 \mathrm{~mm}$ for both models. The margins increase by the factors of 1.07 and 1.50 for the measurements of the first week. The required margins have the highest value in $\mathrm{Z}$ direction for prostate cases. The margins calculated by the models of van Herk and Parker are $1.9 \mathrm{~mm}$ and $2.1 \mathrm{~mm}$, respectively, while, for the first week, the estimated required margins have higher values with the factors of 1.43 and 1.37 , respectively. 


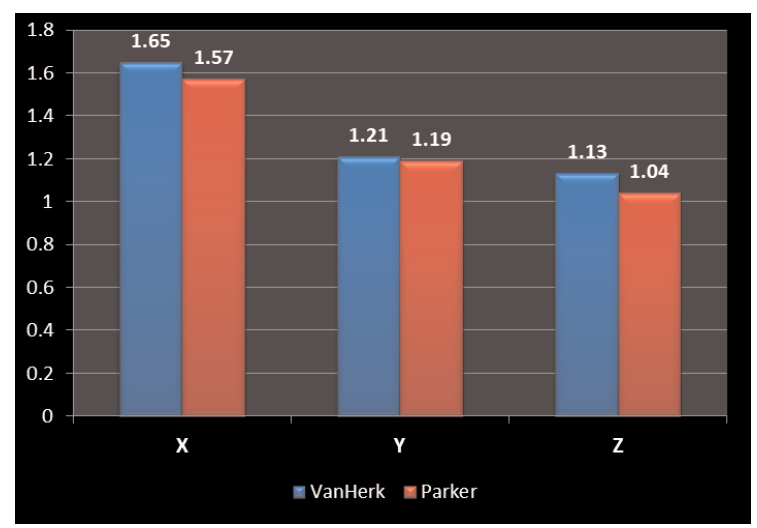

Figure 3. The estimated margins using van Herk (blue) and Parker (red) models for head and neck cases.

The average final shifts for four head and neck cases are $1.14 \pm 0.32 \mathrm{~mm}, 1.22 \pm 0.22 \mathrm{~mm}$ and $0.92 \pm 0.24 \mathrm{~mm}$ in $\mathrm{X}, \mathrm{Y}$ and $\mathrm{Z}$ directions. Figure 3 shows the estimated additional margins based on van Herk and Parker models. The margins have the values in the range of 1.04 and $1.21 \mathrm{~mm}$ in $\mathrm{Y}$ and $\mathrm{Z}$ directions, respectively. Although the estimated margins in X direction exceed the value of $1.5 \mathrm{~mm}$, the margins stay under $1.7 \mathrm{~mm}$ in all directions.

Comparing with the estimated margins for the head and neck cases, the pelvis cases need higher margins in $\mathrm{Y}$ and $\mathrm{Z}$ directions. For instance, the estimated margins using van Herk model are higher with the factor of 1.32 and 1.86 for pelvis cases than head and neck cases. Nevertheless, the required margins in $\mathrm{X}$ direction have closer values for both cases. The ratios of estimated margins are 1.18 and 1.12 for van Herk and Parker models.

\section{DISCUSSION}

IMRT can create steep dose gradients. The location of this gradient in each session with respect to CTV and organs at risk is crucial. The setup procedures and the margins to define PTV gain utmost importance for IMRT applications. With kvCBCT the positioning can be performed according to soft tissue structures. However, it increases treatment session time, and the radiation dose to the patient 8,9 . Besides, the benefits of patient positioning based on 3D over 2D imaging are not clarified, and cannot be installed in all centers as they are relatively expensive. We therefore wanted to address the potential advantages of 3D techniques and to define the margins for different scenarios of setup techniques using $2 \mathrm{D}$ and $3 \mathrm{D}$ imaging.

Interfraction motions of CTV with respect to bony structures are analyzed for 6 patients receiving radiotherapy for prostate cancer, and 4 patients with head and neck cancer. Patients receiving radiotherapy directed to pelvis were evaluated together, and the head and neck cancer patients were analyzed as a second group. In concordance with the literature the rotational corrections were found to be insignificant, so was disregarded in this analysis..$^{10,11} \mathrm{We}$ analyzed the necessary PTV margins for each group when only kv portal imaging is performed every day and found that a margin of 2.1 and $1.5 \mathrm{~mm}$ in all directions would be sufficient in case of pelvic tumors and head and neck cancers respectively if the kv portal images are performed every day.

In the era of IGRT, the necessary margin around CTV to create PTV is continuously being evaluated and a consensus has not been reached yet. ${ }^{12-15}$ In the literature different techniques have been used for setup procedures for head and neck cancer patients. As a result the defined limits are sparse..$^{11,16}$ Even in RTOG trials we observe that the margins are in the range of $3 \mathrm{~mm}-10 \mathrm{~mm}$ for head and neck cancer patients. ${ }^{17,18}$

Kang et al. evaluated the 3D-3D registration setup errors compared to 2D-2D registration in 9 head and neck cancer patients 14 . Seven were immobilized with a 5 point mask and 2 were immobilized with 3 point mask. The masks of 5 patients were cut open around the eyes. They showed that patient positioning corrections by manual 2D-2D registrations were greater than $5 \mathrm{~mm}$ for $30 \%$ of imaging days and they suggested that daily $2 \mathrm{D}$ imaging should be performed for optimal setup of head and neck cancer patients. In another study it was found that even if every other treatment is image guided, about $11 \%$ of all treatments are still subject to three dimensional setup errors of at least $5 \mathrm{~mm}$ for head and neck cancer treatment from random setup error. ${ }^{19}$ The authors concluded that daily imaging in addition to reliable immobilization is necessary. For head and neck cancer patients a minimum $4 \mathrm{~mm}$ margin additional to IGRT margin was proposed when setup was performed according to bony structures. In our study we observed that the additional 
margin necessary over IGRT defined margin is only $1.5 \mathrm{~mm}$ which is lower than series reported in the literature. This difference may be due to the instabilization techniques used. We used head-neck and shoulder thermoplastic mask with fixation at 9 points, standard head rest, knee and feet stabilizers, and shoulder extenders for all patients.

In the study by Bylund et al. ${ }^{20}$ patients were given no direction regarding bladder or bowel emptying, diet or laxative use. They observed that the internal prostate motion was $3.8 \mathrm{~mm}$ when the setup was performed according to bony structures. They also proposed that the motion in the superior inferior direction would be larger if a kvCBCT was used instead of mvCBCT. The bladder prostate interface visualization was low with mvCBCT imaging, and it might lead to underestimation of superior inferior movement. In our retrospective study we observed that a margin of $2.1 \mathrm{~mm}$ in all directions for simplicity is enough in case the kv portal images were performed every day.

Compared to the literature we recorded that the shifts were minimal when kvCBCT was performed after kv portal imaging. ${ }^{21}$ As reported by Pisani et al. kv portal radiographs are qualitatively more effective than $\mathrm{mV}$ based images. ${ }^{22}$ The initial setup procedure performed with $\mathrm{kv}$ portal imaging may be one factor leading to more accurate positioning in our study. Besides, the immobilization procedures were followed strictly both for head and neck cancer patients and for those receiving radiotherapy to the pelvis.

\section{REFERENCES}

1. Al-Mamgani A, Heemsbergen WD, Peeters ST, et al. Role of intensity-modulated radiotherapy in reducing toxicity in dose escalation for localized prostate cancer. Int J Radiat Oncol Biol Phys 73: 685-91, 2009.

2. Cahlon O, Hunt M, Zelefsky MJ. Intensity-modulated radiation therapy: supportive data for prostate cancer. Seminars in Radiation Oncology 18: 48-57, 2008.

3. Moseley DJ, White EA, Wiltshire KL, et al. Comparison of localization performance with implanted fiducial markers and cone-beam computed tomography for on-line image-guided radiotherapy of the prostate. Int J Radiat Oncol Biol Phys 67: 942-53, 2007.
4. Li T, Schreibmann E, Yang Y, et al. Motion correction for improved target localization with on-board conebeam computed tomography. Phys Med Biol 51: 25367, 2006.

5. Thongphiew D, Wu QJ, Lee WR, et al. Comparison of online IGRT techniques for prostate IMRT treatment: adaptive vs repositioning correction. Medical Physics 36: 1651-62, 2009.

6. Parker BC, Shiu AS, Maor MH, et al. PTV margin determination in conformal SRT of intracranial lesions. J Appl Clin Med Phys 3: 176-89, 2002.

7. van Herk M, Remeijer P, Rasch C, et al. The probability of correct target dosage: dose-population histograms for deriving treatment margins in radiotherapy. Int J Radiat Oncol Biol Phys 47: 1121-35, 2000.

8. Kan MW, Leung LH, Wong W, et al. Radiation dose from cone beam computed tomography for image-guided radiation therapy. Int J Radiat Oncol Biol Phys 70: 272-9, 2008.

9. Wen N, Guan HQ, Hammoud R, et al. Dose delivered from Varian's CBCT to patients receiving IMRT for prostate cancer. Phys Med Biol 52: 2267-2276, 2007.

10. Zhang L, Garden AS, Lo J, et al. Multiple regions-ofinterest analysis of setup uncertainties for head-andneck cancer radiotherapy. Int J Radiat Oncol Biol Phys 64: 1559-69, 2006.

11. Wu QJ, Godfrey DJ, Wang Z, et al. On-board patient positioning for head-and-neck IMRT: comparing digital tomosynthesis to kilovoltage radiography and conebeam computed tomography. Int J Radiat Oncol Biol Phys 69: 598-606, 2007.

12. Snir JA, Battista JJ, Bauman G, et al. Evaluation of inter-fraction prostate motion using kilovoltage cone beam computed tomography during radiotherapy. Clin Oncol (R Coll Radiol) 23: 625-31, 2011.

13. Perks J, Turnbull H, Liu T, et al. Vector analysis of prostate patient setup with image-guided radiation therapy via $\mathrm{kV}$ cone beam computed tomography. Int J Radiat Oncol Biol Phys 79: 915-9, 2011.

14. Kang $\mathrm{H}$, Lovelock DM, Yorke ED, et al. Accurate positioning for head and neck cancer patients using 2D and 3D image guidance. J Appl Clin Med Phys 12: 3270, 2011.

15. Li H, Zhu XR, Zhang L, et al. Comparison of 2D radiographic images and $3 \mathrm{D}$ cone beam computed tomography for positioning head-and-neck radiotherapy patients. Int J Radiat Oncol Biol Phys 71: 916-25, 2008.

16. Chen AM, Farwell DG, Luu Q, et al. Evaluation of the Planning Target Volume in the Treatment of Head and Neck Cancer with Intensity-Modulated Radiotherapy: What Is the Appropriate Expansion Margin in the Setting of Daily Image Guidance? International Journal of Radiation Oncology Biology Physics 81: 943-949, 2011. 
17. Lee NY, Zhang Q, Pfister DG, et al. Addition of bevacizumab to standard chemoradiation for locoregionally advanced nasopharyngeal carcinoma (RTOG 0615): a phase 2 multi-institutional trial. Lancet Oncology 13: 172-180, 2012

18. Monaghan MT, Bonner JA, Schaner PE, et al. Dosimetric impact of target definitions on normal structures in head and neck cancer. Head Neck Oncol 3: 34, 2011.

19. Zeidan OA, Langen KM, Meeks SL, et al. Evaluation of image-guidance protocols in the treatment of head and neck cancers. Int J Radiat Oncol Biol Phys 67: 670-7, 2007.

20. Bylund KC, Bayouth JE, Smith MC, et al. Analysis of interfraction prostate motion using megavoltage cone beam computed tomography. International Journal of Radiation Oncology Biology Physics 72: 949-956, 2008.

21. Aoyama H, Azuma $\mathrm{Y}$, Inamura K. Comparison of Daily Prostate Positions during Conformal Radiation Therapy of Prostate Cancer Using an Integrated CT-linear Accelerator System: In-room CT Image versus Digitally Reconstructed Radiograph. Journal of Radiation Research 52: 220-228, 2011.

22. Pisani L, Lockman D, Jaffray D, et al. Setup error in radiotherapy: on-line correction using electronic kilovoltage and megavoltage radiographs. Int $\mathrm{J}$ Radiat Oncol Biol Phys 47: 825-39, 2000.

\section{Correspondence}

\section{Dr. Gözde YAZICI}

Hacettepe Üniversitesi Tıp Fakültesi

Radyasyon Onkolojisi Anabilim Dalı

Sihhiye,45500 ANKARA / TURKEY

Tel: (+90.312) 3052900

Fax: (+90.312) 3092914

e-mail: yazicig@hacettepe.edu.tr 